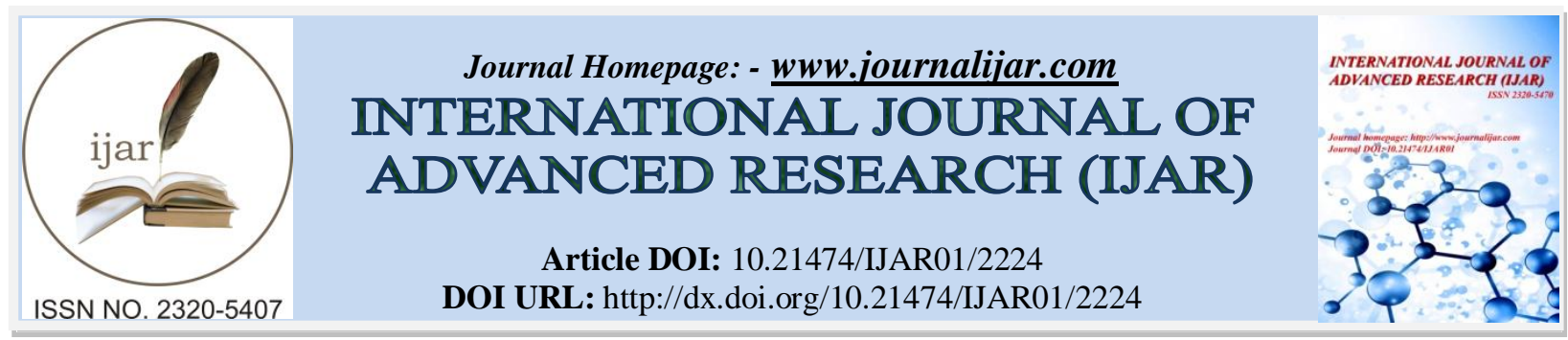

RESEARCH ARTICLE

\title{
MENTAL HEALTH AND SELF-ESTEEM OF TEACHERS: AN INFLUENCE OF INDIAN CASTE- SYSTEM.
}

Dr. Richa Rani Yadav.

(Assistant Prof.) Department of Psychology, D.A.V. P.G. College, B.H.U., Varanasi.

\section{Manuscript Info}

Manuscript History

Received: 28 September 2016

Final Accepted: 30 October 2016

Published: November 2016

Key words:-

Mental Health, Self-esteem ,teachers at tertiary level .

\section{Abstract}

This cross-sectional study was done on 360 (General-N=120, OBC$\mathrm{N}=120, \mathrm{SC}-\mathrm{N}=120$ ) women teachers of higher education belong to Varanasi. They were chosen according to the stratified sampling method. Data collection tool was Mental Health status Inventory (Dr. Anand kumar and Dr. Giridhar P.Thakur) and Self-esteem scale (Dr.M.S Prasad and Dr. G.P Thakur ). Data was analyzed with the help of Mean, S.D., One-way ANOVA and Scheffe's post-Hoc Test. Findings explores that caste is not influencing the Mental Health of women teachers of higher education and also no significant Mean difference found between General/OBC, General/SC and OBC/SC caste teachers on mental health but on the other hand there is significant difference between the teachers of different caste regarding their self -esteem, both personal and social.

Copy Right, IJAR, 2016,. All rights reserved.

\section{Introduction:-}

The caste system in India is a system of social stratification. The 'Jatis'were grouped by Brahminical texts under the four well known caste- categories Varnas: Brahmins, kshatriyas, Vaishyas and Shudras. Certain people were excluded all together, ostracized by all other castes and treated as untouchables. The scheduled caste sometimes referred to as Dalit in contemporary issues. The position of Dalit communities as untouchables in the caste structures was the most important factor that historically led to their exclusion from knowledge and education in traditional Hindu society. They are often reminded of their lower caste status from the attitude and behavior of the higher caste people in some way or other.

In addition to their experiences of untouchables in teachers often experienced traumatic incidences in their communities such as inequality and the abuse by the dominant community. This creates clouds of hesitations which lead them to reveal emotions such as anger, powerlessness and sadness .These feelings attribute to low self esteem and poor mental health.

In Indian society, where social diversity, stratification, deprivation, reservations, social mobility and contempt are operating in such a complex manner, mental health assumes greater significance. Mental health is not simply the absence of mental illness but a positive concept of displaying ability for adaptive social and interpersonal relationships and to reach a harmonious relationship with the society.(V.K.Varma,1992) It is the mental health component of overall health that gives quality and meaning to our lives.(S.K. Khandelwal, 2006)

Corresponding Author:- Richa Rani Yadav.

Address:- (Assistant Prof.) Department of Psychology, D.A.V. P.G. College, B.H.U., Varanasi. 
A stable society has clear role definitions while the social change burden the individual with new role demands. When the individual is unable to cope with socio-technological change, it not only affects the social role but also is instrumental in disturbing the psycho-social homeostasis. (S.D. Sharma, 1987) As such ethnic minorities are subjected to mental health strains; the subject assumes greater importance when sociotechnological changes operate in a diverse and complex manner to influence human behaviour. (V.K. Varma, 1992)

The early developmental process is considered to be largely epigenetic, but the biological material blossoms only in the psycho-social milieu, which has its influence on the development.(V.K.Varma, 1992). In a study, at the age level of four-to-five years, the performance scores of privileged and deprived caste children have been similar, but with advancing age and years of schooling the difference accentuated in favour of the privileged caste children producing a 'torch light effect'. (D.N.Sinha, 1985)

Those suffering from such psychological problems draw arbitrary inferences and automatically draw conclusion regardless of reality. A person suffering from such illness may argue: "I don't need to look at the weather. I know it's raining because I want to go for a walk" (B.Avery, 1999). They suffer from selective abstraction as they focus on a single component of the prevailing environment and ignore other aspects. A whole personal universe is thus derived from a single star. They may argue, "It's raining so everything will go wrong today". Some of the consequences of the birth ascribed low social status are: low self-esteem, confusion of self identity, self hate and perception of the world as a hostile place, hypertension and neuroticism (Paranjpe, 1970).

Mental Health is described as an appropriate balance between the individual, their social group, and the larger environment. These three components combine to promote psychological and social harmony, a sense of well being, self-actualization, and environmental mastery. ( M.A.Khan,1980) This frequently used definition emphasizes, of all: i) balance between the individual, their social group and the larger environment, and ii) promoting psychological and social harmony. While the former is a means and the later is the desired end. This indicates that unless individuals and their social groups interact comfortably, psychological and social harmony cannot be achieved. The absence of such interaction is, no doubt, bound to cause tension and anxiety in their minds and ultimately mental illness or ill-health. Though interaction both at the individual and group/collective levels i.e., at the caste or community level seems important for a health society, do the citizens of India interact with one another with due respect and comfort cutting across their social, particularly their caste, differences? The answer seems to a big "No". There is, no doubt, that there is deep and intense interaction among Indians, but it is within each caste, not between or across castes. Why do most Indians not feel comfortable interacting with members of other castes? Are they afraid? If so, why are they afraid and what are they afraid of? Does it mean that every member of every caste suffers from a kind of mental illness which makes him/her behave in a manner which is not expected of a normal person? The answer seems to a big "Yes". A person belonging to a Brahmin caste develops a phobia at the very site of a Dalits. He therefore avoids facing Dalits on their way. He prefers stepping out of his home only after making sure that no Dalit would come in his vicinity. And if he happens to see a Dalit soon after setting out of his home, he prefers going back home and starting his journey afresh after bathing. The Dalit, on the hand, feels guilty and also develops a fear that he, for having come in the way or vicinity of the Brahmin, would be cursed by the Brahmin; the curse, he feels, would endanger the lives and properties of his own and also of his relatives (Wallace Mandell, 1995).

A teacher is the focal point in an educational system. Kothari Commission (1964 - 66) emphasized in its report that the teachers are having crucial role to play in educational reform. It also stressed the importance of professional development of the teachers at various levels. The conflict model of decision making is of recent origin. We do not have adequate investigative results to definitely prove the relationship between self-esteem and decision making styles. The present study was conducted to examine the relationship between self-esteem and decision making styles of school teachers. 132 teachers of various higher secondary schools (male 82 and female 50) have participated in the study. Leon Mann's Decision Making Questionnaire I and II were used to collect the data. The findings of the study revealed that (i) there is a significant positive relationship exist between self-esteem and vigilant style of decision making, (ii) there is a significant negative relationship exist between self-esteem and non vigilant styles such as hyper vigilance, defensive avoidance, rationalization, buck passing and procrastination styles of decision making.( C.S. Ramanigopal, 2008). According to Coopersmith (1968) self-esteem refers to the individual's personal judgment of his or her worth. The study suggests that children in special schools view themselves as more socially accepted in their new environment. They also appear to feel more comfortable with their ability to learn, 
think that they have more to contribute in the classroom and perceive that their contributions are valued. Thus changes occur in social arena and self-esteem (Cruise, Judge and Sheubrooks 2007).

Tertiary education also referred to as third stage, third level, and post-secondary education, is the educational level following the completion of a school providing a secondary education. The World Bank, for example, defines tertiary education as including universities as well as institutions that teach specific capacities of higher learning such as colleges, technical training institutes, community colleges, nursing schools, research laboratories, centres of excellence, and distance learning centres. Higher education is taken to include undergraduate and postgraduate education, while vocational education and training beyond secondary education is known as further education in the United Kingdom, or continuing education in the United States. Tertiary education generally culminates in the receipt of certificates, diplomas, or academic degrees (Jean Brick, 2006).

\section{Rationale of the study:-}

According to Coopersmith (1968) self-esteem refers to the individual's personal judgment of his or her worth. The study suggests that children in special schools view themselves as more socially accepted in their new environment. They also appear to feel more comfortable with their ability to learn, think that they have more to contribute in the classroom and perceive that their contributions are valued. Thus changes occur in social arena and self-esteem (Cruise, Judge and Sheubrooks 2007). Therefore it was the curiosity of the researcher to assess the difference pattern in the caste of General ,SC and OBC female teachers regarding mental health and self esteem.

\section{Objectives:-}

- To study the difference among General, SC and OBC caste teachers on mental health.

- To examine and compare the scores of Rural \& Urban working women on self-esteem.

\section{Hypotheses:-}

- There will be significant difference among women teachers of General/OBC/SC caste on mental health.

- There will be significant difference among women teachers of General/OBC/SC caste on self-esteem.

\section{Method:- \\ Sample:-}

The present study was conduct on a sample of 360 General $(\mathrm{N}=120)$ OBC $(\mathrm{N}=120)$, and $\mathrm{SC}(\mathrm{N}=120)$ women teachers of higher education from Varanasi. The sample of the present study has been drawn on the basis of stratified proportionate random sampling from PG colleges of Varanasi district. Their age range is 25-50 years.

\section{Tools:-}

Tool 1: The "MITHILA MENTAL HEALTH STATUS INVENTORY" scale is developed by Dr. Anand kumar and Dr. Giridhar P.Thakur (1986). The MMHSI consist five domain are as follow, 1- Egocentrism which consist 10 item, 2- Alienation which consist 10 items, 3- Expression which consist 10 item, 4-Emotional unstability which consist 10 item, 5- Social non-conformity which consist 10 item. Women's responses by indicating the extent which they agree or disagree with the statement, questions is used by indicating 1- strongly agree, 2- agree, 3- cannot say, 4- disagree, 5- strongly disagree, both positive and negative items are included which allow the instrument to asses Mental health in women.

Tool 2 : The "SELF ESTEEM INVENTORY" developed by M.S Prasad and G.P Thakur an assessment tool design to measure the level of Self-esteem .The SEI consist two domain 1- personal perceived self, 2- social perceived self which consist 60 items. Participants' responses by indicating the extent which they are agree or disagree with the statement. Questions is used by indicating 1- absolutely right, 2- highly right, 3- something right, 4- cannot say, 5something wrong, 6- highly wrong, 7- absolutely wrong, both positive and negative items are included which allow the instrument to asses Self-esteem. It is brief and easy in administration and scoring.

\section{Procedure:-}

Above mentioned questionnaire has been administered as per instruction provided in its respective manual. Before starting, all participants has explained properly about the present study and confidentiality of information given by them, has been explicitly assured to them. The instruction of above mentioned measure has been very clearly explained to the participants and demonstrated. The format of responses has been find time limit (20min.) for 
answering. After administering the test the scoring of the data mentioned has been done as per instruction given in the manual.

\section{Results and discussion:-}

Calculation of Mean, SD and one- way ANOVA has been analyzed for the verification of women teachers belongs to General/OBS/SC caste groups.

Results has been shown in table 1,2 and 3.For the egocentrism result table 1 reveals that the Mean of General caste women teachers is $(M=27.99)$, score of $\mathrm{OBC}$ caste $(\mathrm{M}=28.60)$, and score of $\mathrm{SC}$ caste is $(\mathrm{M}=27.33)$, respectively . In the summary of one way ANOVA table- 2 shows [F ratio $(2,357=1.61$, NS] insignificant difference among General/OBC/SC caste groups of women teachers.

The Scheffe's multiple test was applied to find out the significant difference between the Means of caste groups in which table- 3, Mean difference between General and OBC caste (0.61), General and SC (0.27) and OBC and SC $(0.88)$ teachers was also found insignificant on the dimension ego centrism .

For the Alienation dimension result table 1 reveals that the Mean of General caste women teachers is $(\mathrm{M}=21.74)$, score of $\mathrm{OBC}$ caste $(\mathrm{M}=23.39)$, and score of $\mathrm{SC}$ caste is $(\mathrm{M}=23.48)$, respectively. The summary of one way ANOVA table- 2 shows $[\mathrm{F}$ ratio $(2,357=4.69, \mathrm{P}<.01)]$ significant difference among General/OBC/SC caste groups of women teachers of higher education. Therefore caste is dominantly affecting the alienation dimension of Mental Health.

The Post Hoc test was applied to find out the significant difference between the Means of caste groups on Alienation dimension, in which table- 3, Mean difference between General and OBC caste (1.65), General and SC (1.74) and OBC and SC (9.17) teachers were also found significant at .05 level. Hence, General caste teachers were less and $\mathrm{SC}$ teachers were most affected by alienation.

For the expression dimension result table 1 reveals that the Mean of General caste women teachers is ( $\mathrm{M}=28.38)$, score of $\mathrm{OBC}$ caste $(\mathrm{M}=27.58)$, and score of $\mathrm{SC}$ caste is $(\mathrm{M}=28.59)$, respectively. In the summary of one way ANOVA table- 2 shows [F ratio $(2,357=1.93$, NS] insignificant difference among General/OBC/SC caste groups of women teachers. Therefore in three of the caste group expression variable is approximately same.

Table 1:- Mean, SD values for 3 caste groups (General/OBC/SC) on Mental Health.

\begin{tabular}{|l|l|l|l|l|}
\hline Variable & Caste Status & N & Mean & S.D. \\
\hline Egocentrism & General & 120 & 27.99 & 4.34 \\
& OBC & 120 & 28.60 & 3.57 \\
& SC & 120 & 27.73 & 3.64 \\
& Total & 360 & 28.11 & 3.87 \\
\hline \multirow{5}{*}{ Alienation } & General & 120 & 21.74 & 5.02 \\
& OBC & 120 & 23.39 & 5.77 \\
& SC & 120 & 23.48 & 3.88 \\
& Total & 360 & 22.87 & 5.01 \\
\hline \multirow{5}{*}{ Expression } & General & 120 & 28.38 & 4.83 \\
& OBC & 120 & 27.58 & 4.53 \\
& SC & 120 & 28.59 & 3.16 \\
& Total & 360 & 28.18 & 4.25 \\
\hline \multirow{3}{*}{ Emotional-Unstability } & General & 120 & 25.63 & 4.60 \\
& OBC & 120 & 25.71 & 4.50 \\
& SC & 120 & 25.48 & 4.61 \\
& Total & 360 & 25.61 & 4.56 \\
\hline & General & 120 & 26.36 & 3.44 \\
& OBC & 120 & 26.10 & 3.91 \\
& SC & 120 & 27.31 & 3.20 \\
& Total & 360 & 26.59 & 3.56 \\
\hline Mental Health Total & General & 120 & 129.93 & 13.80 \\
& OBC & 120 & 130.74 & 12.67 \\
& SC & 120 & 132.64 & 12.68 \\
\hline
\end{tabular}




\begin{tabular}{|l|l|l|l}
\hline Total & 360 & 131.10 & 13.07
\end{tabular}

The Scheffe's multiple test was applied to find out the significant difference between the Means of caste groups in which table- 3, Mean difference between General and OBC (0.81), General and SC (0.21) and OBC and SC (1.02) caste teachers on expression was also found insignificant.

For the emotional unstability dimension of Mental Health, result table 1 reveals that the Mean of General caste women teachers is $(\mathrm{M}=25.63)$, score of $\mathrm{OBC}$ caste $(\mathrm{M}=25.71)$, and score of $\mathrm{SC}$ caste is $(\mathrm{M}=25.48)$, respectively. In the summary of one way ANOVA table- 2 shows [F- ratio $(2,357=0.08, \mathrm{NS}]$ insignificant difference among General/OBC/SC caste groups of women teachers. Therefore emotional unstability is approximately same in three of the caste group.

Table 2:- Summary of One-way ANOVA for 3 caste groups (General/OBC/SC) on Mental Health

\begin{tabular}{|c|c|c|c|c|c|}
\hline Dependent variable & Source of variance & $\begin{array}{ll}\text { Sum } & \text { of } \\
\text { Square }\end{array}$ & df & $\begin{array}{l}\text { Mean } \\
\text { Square }\end{array}$ & F-ratio \\
\hline \multirow{3}{*}{ Egocentrism } & Between Groups & 48.27 & 2 & 24.14 & \multirow[b]{3}{*}{$1.61 \mathrm{NS}$} \\
\hline & Within groups & 5337.71 & 357 & 14.95 & \\
\hline & Total & 5385.98 & 359 & & \\
\hline \multirow{3}{*}{ Alienation } & Between Groups & 230.57 & 2 & 115.29 & \multirow[b]{3}{*}{$4.70 * *$} \\
\hline & Within groups & 8763.55 & 357 & 24.55 & \\
\hline & Total & 8994.12 & 359 & & \\
\hline \multirow{3}{*}{ Expression } & Between Groups & 69.22 & 2 & 34.61 & \multirow[b]{3}{*}{$1.93 \mathrm{NS}$} \\
\hline & Within groups & 6402.68 & 357 & 17.94 & \\
\hline & Total & 6471.90 & 359 & & \\
\hline \multirow{3}{*}{ Emotional Unstability } & Between Groups & 3.15 & 2 & 1.58 & \multirow[b]{3}{*}{$0.08 \mathrm{NS}$} \\
\hline & Within groups & 7462.62 & 357 & 20.90 & \\
\hline & Total & 7465.77 & 359 & & \\
\hline \multirow{3}{*}{ Social non-confirmity } & Between Groups & 97.17 & 2 & 48.59 & \multirow[b]{3}{*}{$3.90^{*}$} \\
\hline & Within groups & 4443.98 & 357 & 12.45 & \\
\hline & Total & 4541.15 & 359 & & \\
\hline \multirow{3}{*}{ Mental Health Total } & Between Groups & 466.28 & 2 & 233.14 & \multirow[b]{3}{*}{$1.37 \mathrm{NS}$} \\
\hline & Within groups & 60902.91 & 357 & 170.60 & \\
\hline & Total & 61369.20 & 359 & & \\
\hline
\end{tabular}

Note: $* * \mathrm{P}<.01, * \mathrm{P}<.05, \mathrm{NS}=$ Not Significant

Table-3:- Pair wise Mean, Differences for Mental Health dimensions and full scale among three caste-groups following scheffe's test-

\begin{tabular}{|l|l|l|l|}
\hline Dependent variable & Caste Groups- & OBC & SC \\
\hline \multirow{2}{*}{ Egocentrism } & General & .61 & .27 \\
\cline { 2 - 4 } & OBC & X & .88 \\
\hline \multirow{2}{*}{ Elienation } & General & $1.65^{*}$ & $1.74^{*}$ \\
\cline { 2 - 4 } & OBC & $\mathrm{X}$ & 0.09 \\
\hline \multirow{2}{*}{ Emotional Unstability } & General & 0.81 & 0.21 \\
\cline { 2 - 4 } & OBC & $\mathrm{X}$ & 1.02 \\
\hline \multirow{2}{*}{ Social non-confirmity } & General & 0.08 & 0.15 \\
\cline { 2 - 4 } & OBC & $\mathrm{X}$ & 0.22 \\
\hline \multirow{2}{*}{ Mental Health Total } & General & 0.26 & 0.95 \\
\cline { 2 - 4 } & OBC & $\mathrm{X}$ & $1.21^{*}$ \\
\hline & General & 0.82 & 2.72 \\
\cline { 2 - 4 } & OBC & $\mathrm{X}$ & 1.90 \\
\hline
\end{tabular}

Note: $* * \mathrm{P}<.01, * \mathrm{P}<.05$ 
The Scheffe's multiple test was applied to find out the significant difference between the Means of caste groups in which table- 3, Mean difference between General and OBC (0.08), General and SC (0.15) and OBC and SC (0.22) caste teachers on emotional unstability dimension was also found insignificant.

For the Social non-conformity dimension result table 1 reveals that the Mean of General caste women teachers is $(M=26.36)$, score of OBC caste $(M=26.10)$, and score of SC caste is $(M=27.31)$, respectively. The summary of one way ANOVA table- 2 shows [F- ratio $(2,357=3.90, \mathrm{P}<.01)]$ significant difference among General/OBC/SC caste groups of women teachers of higher education. Therefore caste is dominantly affecting the Social non-conformity dimension of Mental Health.

The Post Hoc test was applied to find out the significant difference between the Means of caste groups on Social non-conformity dimension, in which table- 3, Mean difference between General and OBC caste (0.26), General and SC (0.95) teachers were not found significant but Mean difference between OBC and SC (1.21*) caste group of teachers was found significant at .05 level. Therefore $\mathrm{OBC}$ teachers were found poor on social non-conformity than General and $\mathrm{OBC}$ teachers.

For the full scale of Mental Health, result table 1 reveals that the Mean of General caste women teachers is $(M=129.93)$, score of OBC caste $(M=130.74)$, and score of $S C$ caste is $(M=132.64)$, respectively. The summary of one way ANOVA table-2 shows [F- ratio $(2,357=1.37, \mathrm{NS}]$ insignificant difference among General/OBC/SC caste groups of women teachers. Therefore on full scale of Mental Health three of the caste group are approximately same.

The Scheffe's multiple test was applied to find out the significant difference between the Means of caste groups in which table- 3, Mean difference between General and OBC (0.82), General and SC (2.72) and OBC and SC (1.90) caste teachers on emotional instability dimension was also found insignificant.

These studies also supports the findings that female teachers of General, SC and OBC castes were found similar on mental health that early developmental process is considered to be largely epigenetic, but the biological material blossoms only in the psycho-social milieu, which has its influence on the development (V.K.Varma, 1992). Those suffering from such psychological problems draw arbitrary inferences and automatically draw conclusion regardless of reality. A person suffering from such illness may argue: "I don't need to look at the weather. I know it's raining because I want to go for a walk" (B.Avery, 1999).

For the Personal Perceived self dimension result Table- 4 reveals that the Mean of General caste women teachers is $(\mathrm{M}=149.31)$, score of OBC caste $(\mathrm{M}=141.93)$, and score of $\mathrm{SC}$ caste is $(\mathrm{M}=151.31)$, respectively. The summary of one way ANOVA table-5 shows [F- ratio $(2,357=10.07, \mathrm{P}<.01)]$ significant difference among General/OBC/SC caste groups of women teachers of higher education. Therefore caste is dominantly affecting the Personal Perceived self dimension of Self-esteem.

Table-4 :- Mean, SD values for 3 caste groups (General/OBC/SC) on Self-Esteem

\begin{tabular}{|l|l|l|l|l|}
\hline Variable & Caste Status & N & Mean & Std. Deviation \\
\hline Person Perceived Self & General & 120 & 149.31 & 14.37 \\
& OBC & 120 & 141.93 & 15.75 \\
& SC & 120 & 151.31 & 20.46 \\
& Total & 360 & 147.51 & 17.49 \\
\hline Social Perceived Self & General & 120 & 48.11 & 16.06 \\
& OBC & 120 & 143.49 & 15.41 \\
& SC & 120 & 150.24 & 19.29 \\
& Total & 360 & 147.28 & \\
\hline Self-esteem Total & General & 120 & 297.90 & 26.25 \\
& OBC & 120 & 286.48 & 26.53 \\
& SC & 120 & 301.52 & 38.19 \\
& Total & 360 & 295.30 & 31.41 \\
\hline
\end{tabular}

Note: $* * \mathrm{P}<.01,{ }^{*} \mathrm{P}<.05, \mathrm{NS}=$ Not Significant 
The Post Hoc test was applied to find out the significant difference between the Means of caste groups on the Personal Perceived self dimension, in which table-6, Mean difference between General and OBC caste (7.38*), OBC and SC $\left(9.38^{*}\right)$ teachers were found significant at .05 level but Mean difference between General and OBC (2.00) caste group of teachers was found insignificant. Therefore SC teachers were found higher on Personal Perceived self than General and OBC teachers.

For the Social Perceived self dimension of Self-esteem result Table- 4 reveals that the Mean of General caste women teachers is $(M=148.11)$, score of OBC caste $(M=143.49)$, and score of SC caste is $(M=150.24)$, respectively. The summary of one way ANOVA table-5 shows [F- ratio $(2,357=4.94, \mathrm{P}<.01)$ ] significant difference among General/OBC/SC caste groups of women teachers of higher education. Therefore caste is dominantly affecting the Personal Perceived self dimension of Self-esteem.

The Post Hoc test was applied to find out the significant difference between the Means of caste groups on the Social Perceived self dimension, in which table-6, Mean difference between General and OBC caste (4.62), General and SC (2.13) teachers were not found significant but Mean difference between OBC and SC (6.75*) caste group of teachers was found significant at .05 level. Therefore SC teachers were found higher on Social Perceived self than General and OBC teachers.

Table-5:- Summary of One-way ANOVA for 3 caste groups (General/OBC/SC) on Self-esteem

\begin{tabular}{|c|c|c|c|c|c|}
\hline Dependent variable & $\begin{array}{l}\text { Source of } \\
\text { variance }\end{array}$ & $\begin{array}{ll}\text { Sum } \\
\text { Square }\end{array}$ & df & $\begin{array}{l}\text { Mean } \\
\text { Square }\end{array}$ & F-ratio \\
\hline \multirow{3}{*}{ Person Perceived Self } & Between Groups & 5862.42 & 2 & 2931.21 & \multirow{3}{*}{$10.07 * *$} \\
\hline & Within groups & 103905.52 & 357 & 291.05 & \\
\hline & Total & 109767.93 & 359 & & \\
\hline \multirow[t]{3}{*}{ Social Perceived Self } & Between Groups & 2857.09 & 2 & 1428.54 & \multirow{3}{*}{$4.94 * *$} \\
\hline & Within groups & 103205.58 & 357 & 289.09 & \\
\hline & Total & 106062.66 & 359 & & \\
\hline \multirow[t]{3}{*}{ Self-esteem Total } & Between Groups & 14789.31 & 2 & 7394.65 & \multirow{3}{*}{$7.78^{* *}$} \\
\hline & Within groups & 339320.69 & 357 & 950.48 & \\
\hline & Total & 354109.99 & 359 & & \\
\hline
\end{tabular}

Note: $* * \mathrm{P}<.01, * \mathrm{P}<.05, \mathrm{NS}=$ Not Significant

For the full scale of self-esteem, result Table- 4 reveals that the Mean of General caste women teachers is $(M=297.90)$, score of OBC caste $(M=286.48)$, and score of $S C$ caste is $(M=301.52)$, respectively. The summary of one way ANOVA table-5 shows [F-ratio (2,357=7.78, P<.01)] significant difference among General/OBC/SC caste groups of women teachers of higher education. Therefore caste is dominantly affecting Self-esteem of women teachers of higher education.

Table-6:- Pair wise Mean, Differences for Self-esteem dimensions and full scale among three caste groups following scheffe's test-

\begin{tabular}{|l|l|l|l|}
\hline Dependent variable & Caste Groups & OBC & SC \\
\hline Person Perceived Self & General & $7.38^{*}$ & 2.00 \\
\cline { 2 - 4 } & OBC & $\mathrm{X}$ & $9.38^{*}$ \\
\hline \multirow{2}{*}{ Social Perceived Self } & General & 4.62 & 2.13 \\
\cline { 2 - 4 } & OBC & $\mathrm{X}$ & $6.75^{*}$ \\
\hline \multirow{2}{*}{ Self -esteem Total } & General & $11.42^{*}$ & 3.63 \\
\cline { 2 - 4 } & OBC & $\mathrm{X}$ & $15.04^{*}$ \\
\hline
\end{tabular}

Note: $* * \mathrm{P}<.01, * \mathrm{P}<.05$

The Scheffe's multiple test was applied to find out the significant difference between the Means of caste groups on the Personal Perceived self dimension, in which table-6, Mean difference between General and OBC caste (11.42), OBC and SC (15.04) teachers were found significant at .05 level but the Mean difference between General and SC (3.63) caste group of teachers was found insignificant. Therefore OBC teachers were found lower on the full scale of self-esteem than General and SC women teachers of higher education. 


\section{Implications}

This study measures the two vital aspects of individual's personality- Mental Health and Self-Esteem. This study would provide insight for the future researches in this direction. If the focused and honest contribution of the policies get applicable for the upliftment of socially deprived class at large, will really help them to improve and boost their mental health and self-esteem allot.

\section{Conclusion}

- General caste teachers were less and SC teachers were most affected by alienation.

- In three of the caste group expression variable is approximately same.

- OBC teachers were found poor on social non-conformity than General and OBC teachers means to say that teachers from $\mathrm{OBC}$ class many times try to do the things beyond the social norms.

- Three of the caste groups of teachers have good mental health.

- SC teachers were found higher on Person Perceived self and Social perceived self than General and OBC teachers. It seems that getting focused privilege from government because of social deprivation leads them to more concern about their self and social perceived self.

- $\quad$ OBC teachers were found lower on the full scale of self-esteem than General and SC women teachers of higher education.

\section{References:-}

1. Avery, Brice (1999), Principles of Psychotherapy, HarperCollins Publishers India, New Delhi.

2. Berreman, G. D. (1979), Caste and Other Inequities, Folklore Institute, Meerut.

3. Brick, Jean (2006). "What is academic culture?". Academic Culture: A Student's Guide to Studying at University. Sydney, N.S.W: National Centre for English Language Teachingand Research. pp. 1-10. ISBN 9781-74138-135-1.

4. Coopersmith, S. (1967). Antecedents of Selfesteem. San Fransico: W. H. Freeman and Company.

5. Cruise, K., Judge, M., and Sheubrooks, J. (2007). Quantifying Changes in Learning Disabled Students' Selfesteem Following Special School Placement. Mental Health and Learning Disabilities Research and Practice, 5, 278-287.

6. Khan, M.A. (1980), Scheduled Castes and Their Status in India, Uppal, New Delhi Sharma, Khandelwal, S.K.(2006). The Joys of Mental Health: Some popular writings of Dr NN Wig.

7. Book Review. Indian Journal of Psychiatry, 48(3): 207- 208.

8. Mandell, Wallace (1995). "Origins of Mental Health, The Realization of an Idea".Johns Hopkins Bloomberg School of Public Health. Baltimore, MD: Johns Hopkins $\quad$ University. Retrieved 9 June 2015.

9. Paranjpe, A. C. (1970), Caste, Prejudice and the Individual, Lalvani, Bambay S.D.

10. Ramanigopal,C.S.(2008). Self-Esteem and Decision Making Styles of School Teachers.

11. Journal of the Indian Academy of Applied Psychology, 35(SI):145-150.

12. Sharma (1987). Impact of social change on mental health - Presidential address, Indian Journal of Social Psychiatry, 3(182) : 3-17

13. Sinha D.N. Cognitive and Motivational Correlates of Deprivation for the Education of Scheduled caste Children. J Pers Clin Stud. 1985;1:11-6

14. Varma, V.K.(1992). Social disadvantage: Mental health and Social justice. Indian Journal of Social Psychiatry, $8(3-4): 8-12$.

15. Varma,V.K.(2009).Social disadvantage, Mental Health and Social Justice. In: Varma VK, editor. Culture, Personality and Mental Illness. New Delhi: Jaypee Brothers Medical Publishers.. 